International Research Journal of Engineering, IT \& Scientific Research
Available online at https://sloap.org/journals/index.php/irjeis/
Vol. 8 No. 2, March 2022, pages: 36-48
ISSN: 2454-2261
https://doi.org/10.21744/irjeis.v8n2.2060

\title{
The Effect of Using Various Tea Types on the Characteristics of Wong Tea Balinese Traditional Beverage
}

\author{
Anak Agung Nanak Antarini ${ }^{a}$ \\ Ni Putu Agustini ${ }^{b}$ \\ I Komang Agusjaya Mataram ${ }^{c}$
}

Article history:

Submitted: 27 Dec 2021

Revised: 09 Jan 2022

Accepted: 18 Feb 2022

Keywords:

microbial characteristics; organoleptic;

tea;

traditional beverage;

various tea;

\begin{abstract}
This study aimed to determine the effect of various types of tea solutions on the characteristics of Wong Tea. This study used a Randomized Block Design (RBD) of 4 treatments with various types of tea solutions with 4 replications. The results showed that there were significant differences in the organoleptic quality including the taste, aroma, and color of Wong tea. The results of the research on $\mathrm{pH}$, total acid, alcohol content, and total soluble solid showed no significant difference. The $\mathrm{pH}$ of Wong tea ranged from $\mathrm{pH}$ $3.28-\mathrm{pH} 3.35$, total soluble solid ranged from $13.90^{\circ}$ Brix $-13.95^{\circ}$ Brix, total acidity of Wong tea ranged from $1.58 \%-1.72 \%$. The alcohol content of Wong tea ranges from $0.33 \%-0.41 \%$. The results of this study also showed that there was a significant difference in antioxidant activity and phenol levels of Wong tea, i.e., the antioxidant capacity of Wong tea ranged from $6.50 \%-7.30 \%$. The components that act as antioxidants in Wong tea ingredients come from phenolic compounds. Phenol levels in Wong tea ranged from $125.80 \mathrm{mg} \%$ - $141.10 \mathrm{mg} \%$.
\end{abstract}

International research journal of engineering, IT \& scientific research (C) 2022. This is an open access article under the CC BY-NC-ND license (https://creativecommons.org/licenses/by-nc-nd/4.0/).

\section{Corresponding author:}

Anak Agung Nanak Antarini,

Department of Nutrition Health Polytechnic Denpasar, Indonesia.

Email address: nanakantarini20@gmail.com

\footnotetext{
a Department of Nutrition Health Polytechnic Denpasar, Indonesia

b Department of Nutrition Health Polytechnic Denpasar, Indonesia

c Department of Nutrition Health Polytechnic Denpasar, Indonesia
} 


\section{Introduction}

Tea is a plant whose leaves can be used for beverage. Classification of tea is based on the tea leaves quality and processing. There are six types of tea, i.e., green tea, yellow tea, white tea, oolong tea, black tea, and dark tea (Sutarmi, 2005). This difference is based on the degree of oxidation of the polyphenols present in the tea. Tea obtained from processing tea leaves can be regarded as functional food because it has high antioxidants, hypocholesterolemic, and anti-obesity properties. The use of various tea leaves that contain antioxidants as a medium in brewing Wong tea has not been studied until now (Hopkins et al., 2000; Guo et al., 2014). Wong tea is one of the traditional Balinese tea beverages that has a distinctive sweet-and-sour taste and aroma. Wong tea is made from sugar water (sweet tea water) which is fermented using a starter from mushroom (Wong) wine. This mushroom (Wong) wine lives in sugar water to sustain its life and is usually kept in sweet tea water. This fermented water is consumed with the sweet tea water as the basic ingredient for fermentation. The resulting water solution is called Wong tea (mushroom tea). Fermentation will turn the sugar into alcohol and then the bacteria will turn the alcohol into acid. Then, the sweet tea water turns into a slightly sweet-sour taste. This mushroom tea is usually consumed by the people of Guwang Sukawati as their common beverage. Some research results show that lactic acid bacteria (LAB) grows maximally on fermented Wong tea in storage length of 6 - 9 days, i.e., reaching Total LAB as much as $2.57 \times 104$ to $2.86 \times 106 \mathrm{cfu} / \mathrm{ml}$ with a pH of $2.88-2.59$ according to a study by Antarini et al. (2018); Sutarmi (2005), that LAB grows maximally in week I. Wong tea using tea solutions from various types of tea leaves is expected to produce functional properties, such as antioxidants, and will affect its consumer's physical quality, organoleptic chemistry, and it has a potential as a probiotic beverage (Kung Jr et al., 2018; Tyagi et al., 2007).

\section{Research Methods}

This is an experimental study with an experimental design using a Randomized Block Design (RBD) with 4 treatments and 4 replications. Then, organoleptic tests were carried out, and also analyzing $\mathrm{pH}$, total soluble solid, alcohol content, antioxidant activity, and phenol content of Wong tea. Analysis of $\mathrm{pH}$ was using a $\mathrm{pH}$ meter, total acid content was using titration, total soluble solid was using a refractometer, alcohol content was using an alcoholmeter Apriantono et al. (1989), antioxidant activity was using the DPPH method, and phenol levels was using spectrophotometry. Processing and analyzing data were performed with variance (Gaspersz, 1995). This study consisted of 4 treatments, i.e., using various the following types of tea, P1: Black tea (brand x), P2: Black tea (brand y), P3: Oolong tea, P4: Green tea. The ingredients used in making Wong tea are tuak (palm wine) drinks taken from palm wine producers in the Guwang village, Sukawati, Gianyar. A solution of tea water (from various brands of tea brewed with hot water) was added with sugar, while some chemicals were also used, such as citrate phosphate buffer, $70 \%$ ethanol, Folinciaocalteau, $\mathrm{Na} 2 \mathrm{CO} 3, \mathrm{ml} 0.1 \mathrm{mM}$ DPPH solution. The tools used in making Wong tea are stoves, pans, and jars. For chemical analysis, the tools are $\mathrm{pH}$ meters, test tubes, measuring cups, vortex mixers, Erlenmeyer, cuvettes, and spectrophotometers (Kaur et al., 2019; Ilango \& Antony, 2021).

The procedure for making Wong tea Drink in this study was: a. 3 grams of various types of tea leaves were brewed in $1000 \mathrm{ml}$ of hot water for 3 minutes. Then, $15 \%$ w/v granulated sugar was added and stirred until the sugar completely melted; b. After the tea water cooled down to a temperature of $30^{\circ} \mathrm{C}$ (room temperature), then $8 \% \mathrm{w} / \mathrm{v}$ of nata Wong (mushroom) was added as a starter; c. The solution was fermented for 6 days; d. Then, organoleptic and chemical tests were performed on this Wong tea solution. The organoleptic test was carried out by a moderately trained panel of 30 people, i.e., the Guwang Sukawati village community who were familiar and used to consume Wong tea with 5 hedonic scales. Degree of Acidity $(\mathrm{pH})$ was analyzed by using a $\mathrm{pH}$ meter (Sudarmadji et al., 1997). Total soluble solid was analyzed by using Refractometer; Alcohol Level was analyzed by using Alcoholmeter; Total Acid Level was analyzed by using titration; Antioxidant activity was analyzed by DPPH method and phenol content by spectrophotometer. The data obtained were presented in the form of tables, graphs, and images which were then processed using a computer software program with statistical analysis of variance. If different results were obtained, the Least Significant Difference Test (BNT) followed (Gaspersz, 1995).

Antarini, A. A. N., Agustini, N. P., \& Mataram, I. K. A. (2022). The effect of using various tea types on the characteristics of wong tea balinese tradisional beverage. International Research Journal of Engineering, IT \& Scientific Research, 8(2), 36-48.

https://doi.org/10.21744/irjeis.v8n2.2060 


\section{Results and Discussions}

\section{Research results \\ Nutritional and chemical characteristics of Wong tea}

The nutritional characteristics, i.e., antioxidant activity and phenol levels, in Wong tea showed significant differences $(\mathrm{P} \leq 0.05)$. The average value of the nutritional characteristics analysis can be seen in table 1 .

Table 1

Average value of nutritional characteristics analysis in Wong tea

\begin{tabular}{cccc}
\hline Treatment & \multicolumn{2}{c}{ Average Value } \\
& Antioxidant activity $100 \mathrm{ppm}(\%)$ & IC $50(\mathrm{ppm})$ & Phenol levels $(\mathrm{mg} / 100)$ \\
\hline P1 & $6.50^{\mathrm{a}}$ & $1047^{\mathrm{a}}$ & $125.80^{\mathrm{a}}$ \\
P2 & $6.40^{\mathrm{ab}}$ & $9538.90^{\mathrm{ab}}$ & $129.80^{\mathrm{a}}$ \\
P3 & $5.20^{\mathrm{a}}$ & $11380^{\mathrm{a}}$ & $135.20^{\mathrm{a}}$ \\
P4 & $7.80^{\mathrm{a}}$ & $7142.60^{\mathrm{c}}$ & $141.10^{\mathrm{ab}}$ \\
\hline
\end{tabular}

\section{Antioxidant activity}

The results of the analysis of variance showed that the type of tea had a very significant effect $(\mathrm{P}<0.05)$ on the antioxidant capacity of Wong tea. Table 1 shows the antioxidant capacity of Wong tea ranging from $5.20 \%$ to $7.80 \%$. The highest antioxidant capacity was obtained from Wong tea in treatment P4 (green tea), which was $7.80 \%$, with the lowest antioxidant capacity found in Wong tea in treatment P3 (black tea), which was 5.20\%. Phenol levels and antioxidant activity have a positive correlation, the higher the phenol content, the higher the antioxidant capacity in tea. For more details, the average value of antioxidant activity can be seen in Figure 1.

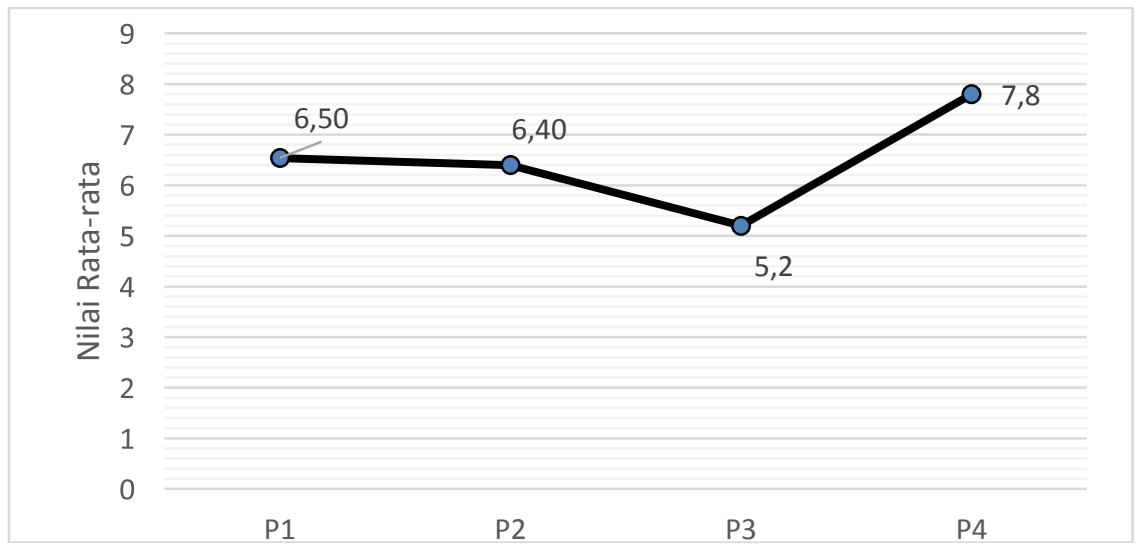

Figure 1. The antioxidant activity of Wong tea

\section{Phenol levels}

The results of the analysis of variance showed that the type of tea had a very significant effect $(\mathrm{P}<0.05)$ on the phenol levels of Wong tea. Table 1 shows the phenol levels of Wong tea were ranging from $125.80 \mathrm{mg} \%$ to 141.10 $\mathrm{mg} \%$. The highest phenol level was obtained from Wong tea in treatment P4 which was $141.10 \mathrm{mg} \%$ with the lowest phenol content found in Wong tea in treatment P1 which was $125.80 \mathrm{mg} \%$. The results of the determination of the total phenol levels were positively correlated with its antioxidant activity. For more details, the average value of phenol levels can be seen in Figure 2. 


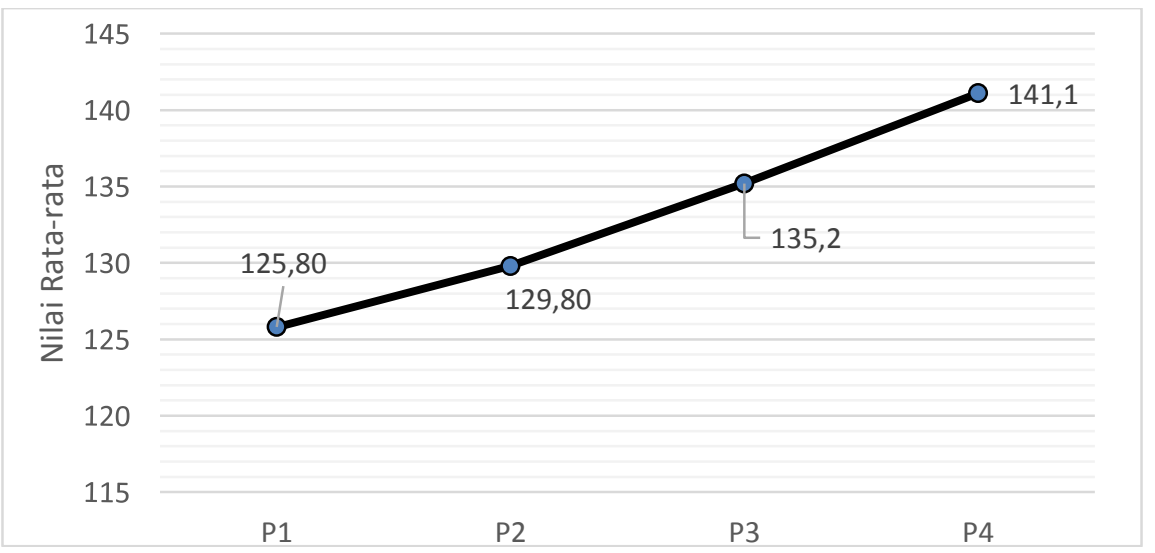

Figure 2. Phenol levels of Wong tea

Chemical analysis carried out on Wong tea were analyses of $\mathrm{pH}$, total acid, total soluble solids, alcohol content, antioxidant capacity, and phenol content. Based on Table 2, the results showed that the pH, TSS, and total acid of Wong tea with the use of different types of tea resulted in insignificant differences $(\mathrm{P}>0.05)$.

Table 2

Average value analysis of chemical characteristics in Wong tea

\begin{tabular}{lcccc}
\hline Treatment & & & Average Value \\
& $\mathrm{pH}$ & TSS (Brix) & Total Acid (\%) & Alcohol Level (\%) \\
\hline P1 & $3.34^{\mathrm{a}}$ & $13.95^{\mathrm{a}}$ & $1.68^{\mathrm{a}}$ & $0.40^{\mathrm{a}}$ \\
P2 & $3.35^{\mathrm{a}}$ & $13.90^{\mathrm{a}}$ & $1.72^{\mathrm{a}}$ & $0.33^{\mathrm{a}}$ \\
P3 & $3.28^{\mathrm{a}}$ & $13.95^{\mathrm{a}}$ & $1.58^{\mathrm{a}}$ & $0.40^{\mathrm{a}}$ \\
P4 & $3.28^{\mathrm{a}}$ & $13.95^{\mathrm{a}}$ & $1.65^{\mathrm{a}}$ & $0.41^{\mathrm{a}}$ \\
\hline
\end{tabular}

\section{Degree of acidity $(p H)$ in Wong tea}

The degree of acidity $(\mathrm{pH})$ in Wong tea is based on the use of the type of tea, i.e., $\mathrm{pH} 3.28$ - $\mathrm{pH} 3.35$ after 6 days of fermentation. The results of the analysis of variance showed the use of various types of tea on the $\mathrm{pH}$ of Wong tea was not significant $(\mathrm{P}>0.05)$. The $\mathrm{pH}$ of Wong tea can be seen in Table 2.

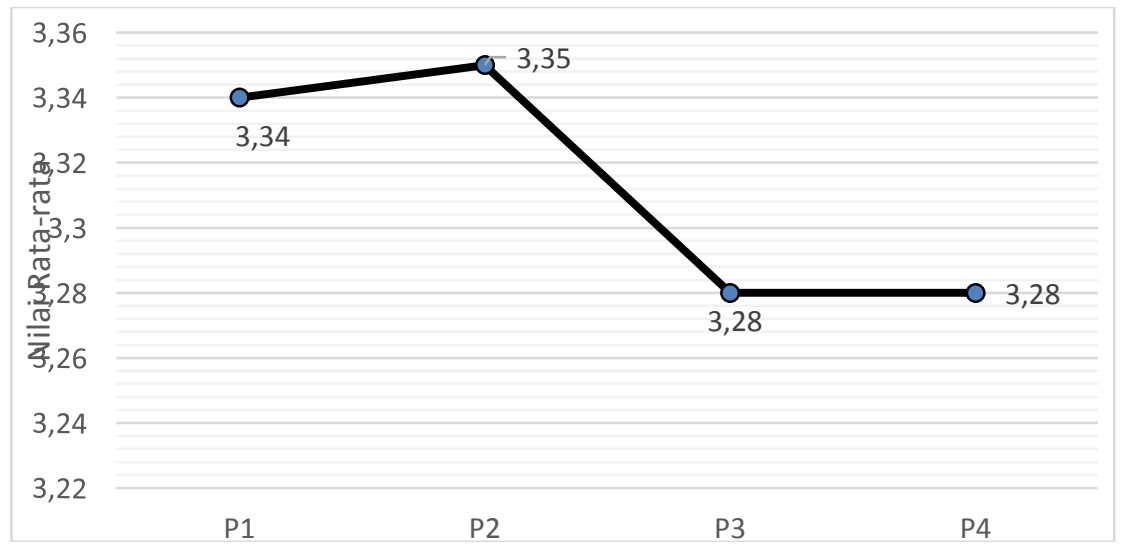

Figure 3. The degree of acidity of Wong tea

Antarini, A. A. N., Agustini, N. P., \& Mataram, I. K. A. (2022). The effect of using various tea types on the characteristics of wong tea balinese tradisional beverage. International Research Journal of Engineering, IT \& Scientific Research, 8(2), 36-48. 


\section{TSS/Total soluble solids}

The results of the analysis of variance showed the use of various types of tea on the total soluble solid of Wong tea was not significant $(\mathrm{P}>0.05)$. Based on Table 2, the results of Wong tea TSS with the use of different types of tea resulted in insignificant differences. The results showed that the total soluble solids ranged from $13.90^{\circ} \mathrm{Brix}-$ $13.95^{\circ}$ Brix. Total soluble solids can be used to interpret the amount of sugar contained in Wong tea. For more details, the Average Value of total soluble solids can be seen in Figure 4.

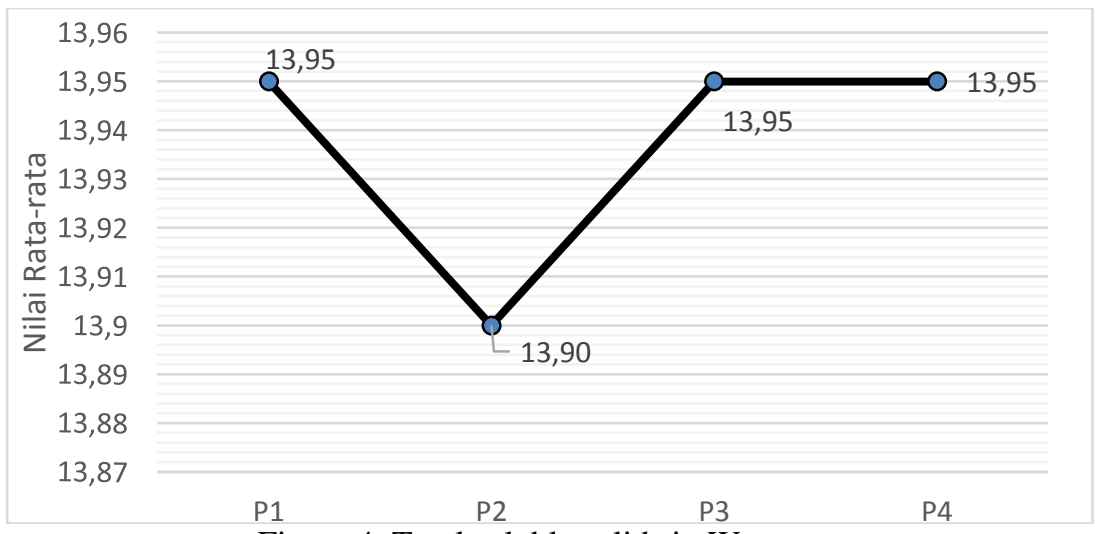

Figure 4. Total soluble solids in Wong tea

\section{Total acid}

The results of the analysis of variance showed that various types of tea had no significant effect at the 5\% test level on the Total Acid content of Wong tea. Table 2 shows the Total Acid of Wong tea ranged from $1.58 \%-1.72 \%$. The highest total acid was obtained from Wong tea made from P2 tea, which was $1.1 .72 \%$, while the lowest total acid was obtained from P3 tea, which was $1.58 \%$. For more details, the Average Value of Total Acid can be seen in Figure 5.

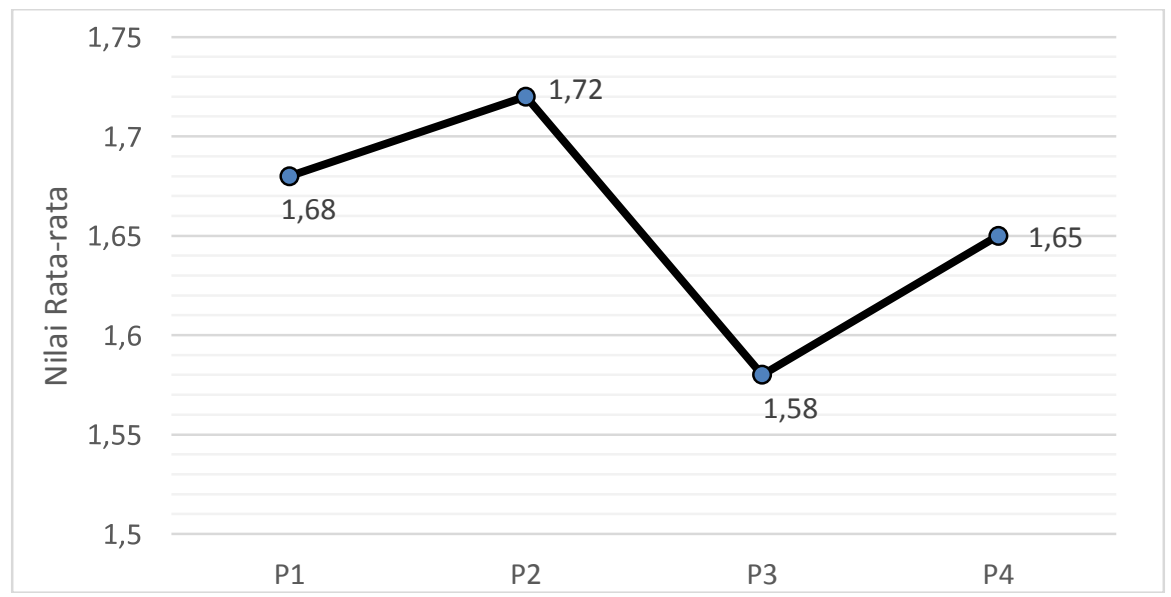

Figure 5. Total acid level in Wong tea

\section{Alcohol level}

The results of the analysis of variance showed that various types of tea had no significant effect on the $5 \%$ test level on the Alcohol Level of Wong tea. Table 2 shows the Alcohol Level of Wong tea ranged from $0.33 \%-0.41 \%$. For more details, Average Value Alcohol Level in Wong tea can be seen in Figure 6. 


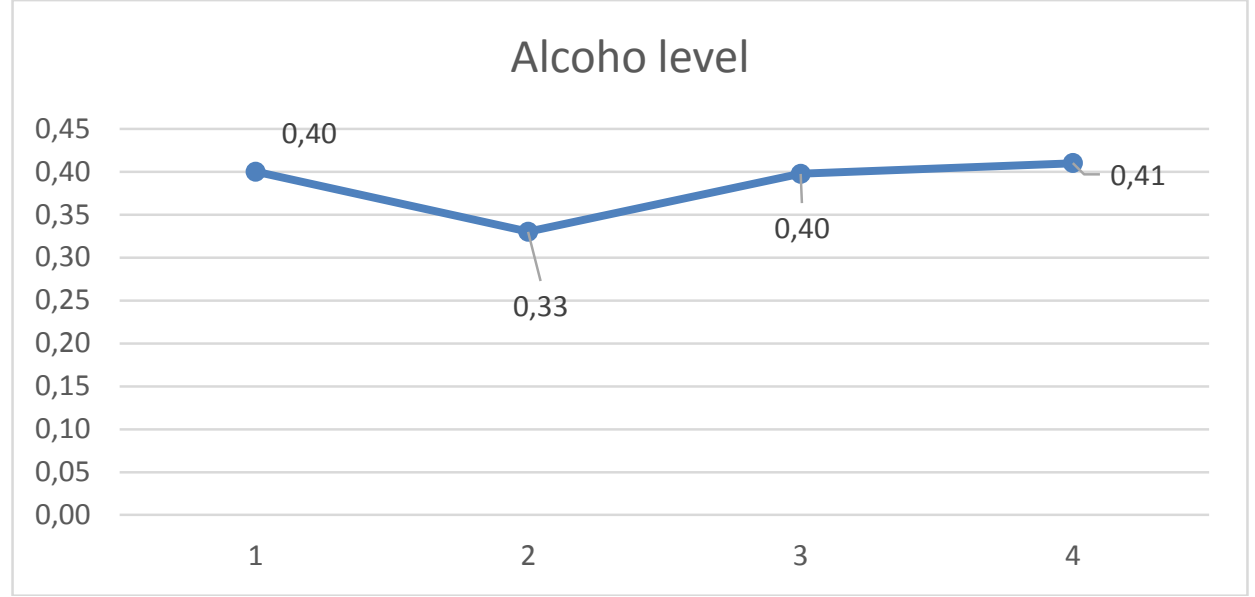

Figure 6. Alcohol level in Wong tea

\section{Microbial characteristics}

Total microbes

The results of the analysis of variance showed that various types of tea had no significant effect at the 5\% test level on the total microbes of Wong tea. For more details, the Total Plate Count (TPC) of Wong tea can be seen in Table 3.

Table 3

Average value analysis of microbial characteristics

\begin{tabular}{ccc}
\hline Treatment & \multicolumn{2}{c}{ Average Value } \\
& Total Microbes $(\mathrm{cfu} / \mathrm{g})$ & Total LAB $(\mathrm{cfu} / \mathrm{g})$ \\
\hline P1 & $832.50^{\mathrm{a}}$ & $9550^{\mathrm{a}}$ \\
P2 & $1167.50^{\mathrm{a}}$ & $5800^{\mathrm{a}}$ \\
P3 & $6000^{\mathrm{a}}$ & $11525^{\mathrm{a}}$ \\
P4 & $32950^{\mathrm{a}}$ & $51025^{\mathrm{a}}$ \\
\hline
\end{tabular}

Note: different letters behind the Average Value indicate a significant difference with a 5\% test level.

Total Microbes are expressed in Total Plate Count (TPC) on Wong tea products. The study showed that total microbes in Wong tea ranged from $8.3 \times 10^{2}$ to $3.3 \times 10^{4} \mathrm{cfu} / \mathrm{g}$.

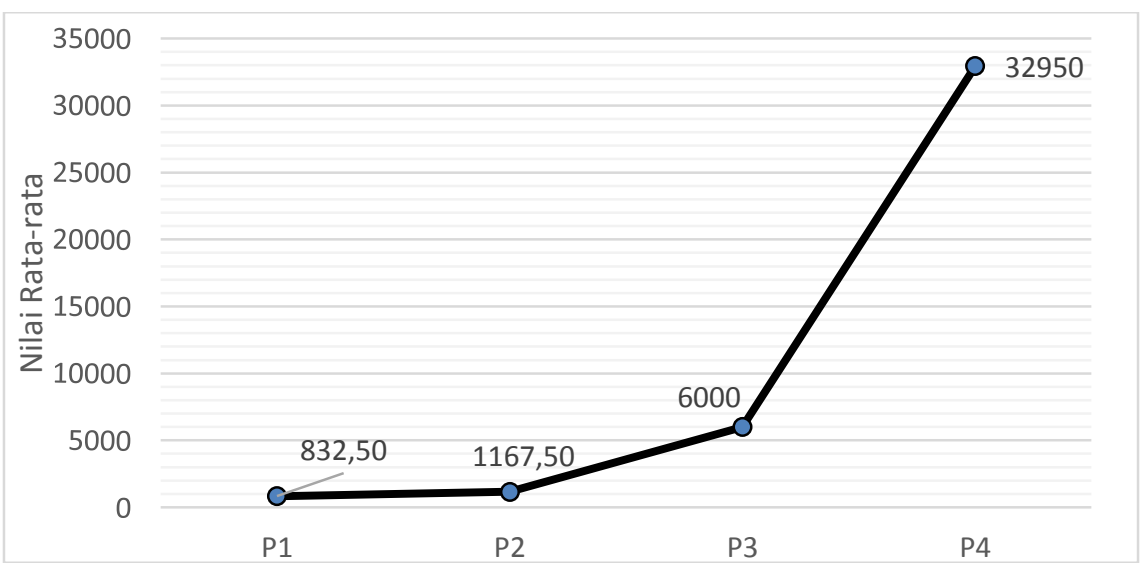

Figure 7. Total microbes in Wong tea

Antarini, A. A. N., Agustini, N. P., \& Mataram, I. K. A. (2022). The effect of using various tea types on the characteristics of wong tea balinese tradisional beverage. International Research Journal of Engineering, IT \& Scientific Research, 8(2), 36-48. https://doi.org/10.21744/irjeis.v8n2.2060 


\section{Total lactic acid bacteria $(L A B)$}

The results of the analysis of variance showed that various types of tea had no significant effect at the $5 \%$ test level on LAB in Wong tea. Total LAB in Wong tea products ranges from $5.8 \times 10^{3}$ to $5.1 \times 10^{4} \mathrm{cfu} / \mathrm{g}$. For more details, Wong tea's Total LAB can be seen in Table 3 and the Average Value of total LAB can be seen in Figure 8.

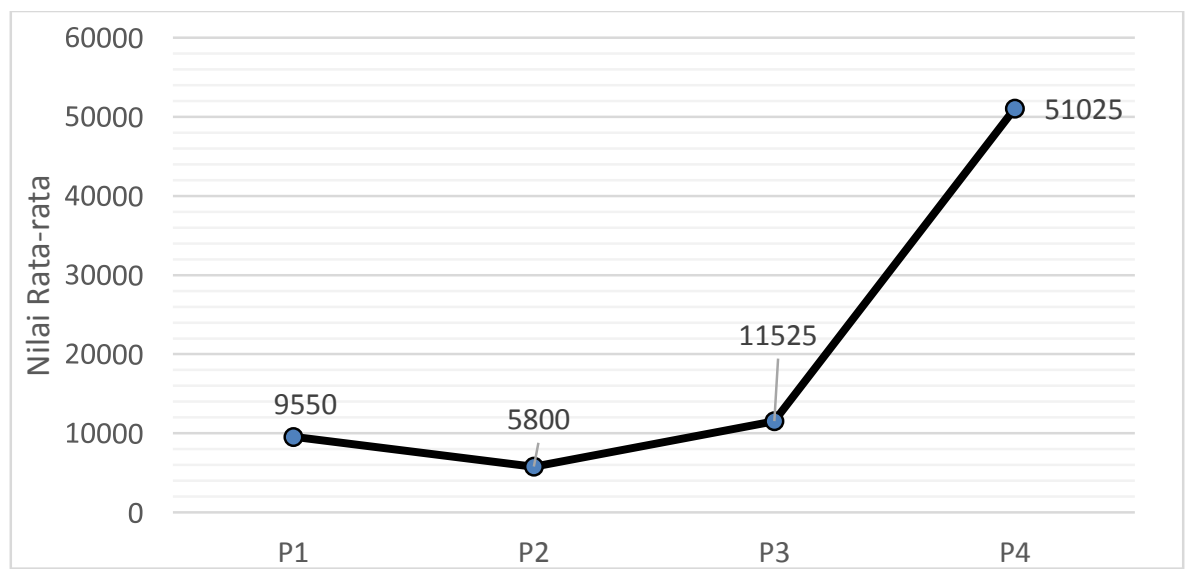

Figure 8. Total LAB in Wong tea

\section{Organoleptic characteristics of Wong tea}

The organoleptic test of Wong tea includes taste, aroma, color, and also the overall acceptance with a preference test (hedonic test) with 5 hedonic scales. For hedonic quality on taste quality and aroma quality were using 3 hedonic quality scales. Organoleptic assessment was performed by a total of 25 panelists who are familiar with Wong tea products. Based on the results of the analysis of variance on organoleptic tests for taste, aroma, color, and also the overall acceptance, color quality, taste quality, and aroma quality in Wong tea, there was a significant difference $(\mathrm{P}<$ 0.05). For more details, Wong tea's Organoleptic Test with 4 treatments can be seen in Figure 9.

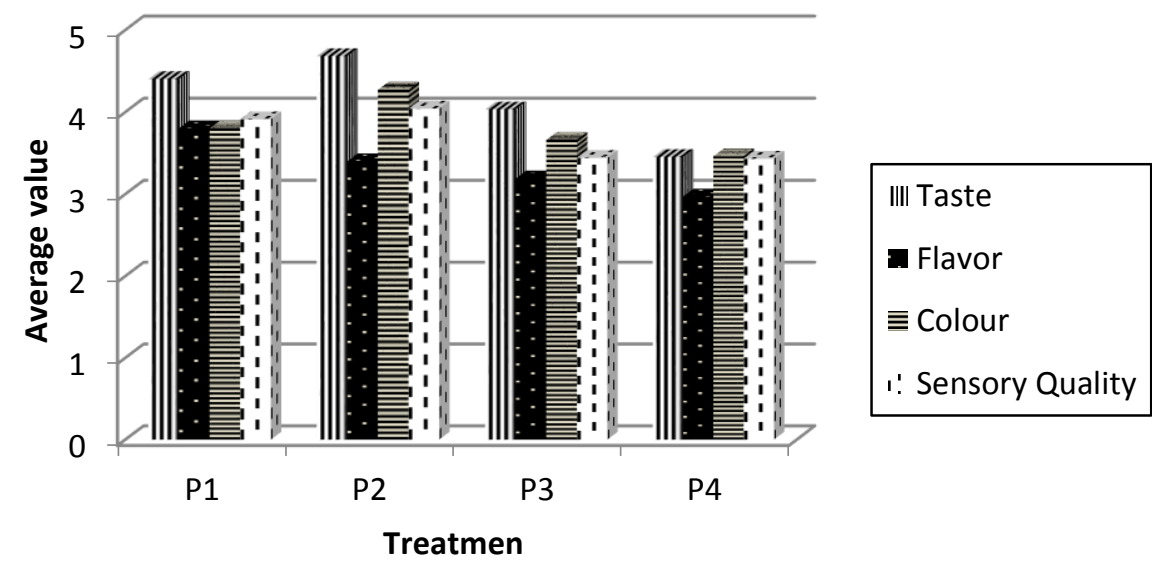

Figure 9. Organoleptic Test for Wong tea

\section{Discussion}

Antioxidants are compounds that protect cells from the harmful effects of reactive oxygen free radicals when associated with disease. These free radicals can come from the body's metabolism or other external factors. Protein lipids and DNA from healthy human cells are good sources of electron pairs. Oxidative conditions can cause protein 
and DNA damage, cancer, aging, and other diseases. Chemical components that act as antioxidants are phenolic and polyphenolic compounds. These compounds are widely found in nature, especially in plants and have the ability to capture free radicals. Antioxidants are found in many foodstuffs, including vitamins $\mathrm{E}$ and $\mathrm{C}$ and carotenoids (Ruslin et al., 2021).

The results of the study on antioxidant activity showed that Wong tea from 4 treatments had the highest antioxidant activity at treatment P4 (7.8\%) and the lowest at P3 (5.2\%). The effectiveness of a sample to scavenge free radicals from the DPPH method is named IC50. The definition of IC50 is a concentration that can reduce 50\% of DPPH free radicals. The smaller the IC50 value, the greater the antioxidant activity. The results of this study obtained IC50 values of $1047 \mathrm{ppm}-11380 \mathrm{ppm}$. This was caused by heating during brewing or beverage processing. A substance can be said to be a strong antioxidant if it has an IC50 value of less than $200 \mathrm{ppm}$. Heating can accelerate the oxidation of antioxidants contained in a material. Oxidation results in decreased antioxidant activity with different levels which are influenced by the type of antioxidant components in the material (Hastuti, 2014; Simanjuntak et al., 2016). The components that act as antioxidants in Wong tea drink are derived from phenolic compounds. Phenol levels in Wong tea ranged from $125.80 \mathrm{mg} \%-141.10 \mathrm{mg} \%$. Green tea contains more phenol levels than black tea (Fessard et al., 2017).

The degree of acidity $(\mathrm{pH})$ is one of the intrinsic factors of food ingredients that can affect microbial growth. Based on this study, it is known that the $\mathrm{pH}$ of Wong tea ranges from $\mathrm{pH} 3.28-\mathrm{pH} 3.35$ which does not significantly affect the $5 \%$ test level on the $\mathrm{pH}$ of Wong tea. This happens because the fermentation of Wong tea synthesizes sugar into cellulose and triggers the formation of acetic acid and lactic acid so that it decreases to a $\mathrm{pH}$ of 3.0-2.0. Based on the $\mathrm{pH}$ range, these bacteria are classified as acidophilic bacteria, i.e., a group of microorganisms that can grow well at a $\mathrm{pH}$ of 2.0-5.0. In general, the higher the acid content of a material, the lower the $\mathrm{pH}$ value. The decrease in the $\mathrm{pH}$ of Wong tea is thought to be caused by an increase in the concentration of acidic substances during the fermentation process (Simanjuntak et al., 2016). The decrease in $\mathrm{pH}$ occurs because during the fermentation process, yeast and bacteria synthesize sucrose into organic acids such as acetic acid and gluconic acid and several other organic acids, and the increased concentration of these organic acids results in a decrease in $\mathrm{pH}$ in the fermentation medium. This is due to the accumulation of acids and an increase in the number of $\mathrm{H}+$ protons as a result of the metabolism of bacteria and yeasts in the medium (Agestiawan et al., 2014; Coton et al., 2017).

Total soluble solids can be used to interpret the amount of sugar contained in the material, in this case sugar. The average TSS of Wong tea showed no significant difference. Based on the results of this study, because it used a sugar content of $15 \%$ and was fermented for 6 days, the longer the fermentation time the sugar content decreases. This is because the fermentation process converts glucose into ethanol and $\mathrm{CO} 2$, and reacts with water to form carbonic acid. This is presumably because the longer the fermentation time, the sugar contained in kombucha will be overhauled by bacteria and yeast into organic acids. Kombucha products contain yeast and bacteria that metabolize sucrose to produce organic acids such as acetic acid and gluconic acid (Sreeramulu et al., 2000). This is in line with a previous study which stated that the total acid content increased with the length of fermentation time in seaweed kombucha. Naland (2004), further states that kombucha tea produces organic acids, including glucuronic acid, acetic acid, gluconic acid, chondroitin sulfate acid, hyaluronic acid, hyaluronidase acid, and amino acids (Huang et al., 2014; Kraujalytė et al., 2016).

The alcohol level of Wong tea occurs due to the breakdown of sugar by a symbiosis of bacteria and yeast that remodeled the sugar in Wong tea into ethanol and other compounds with increasing fermentation time and this process is known as alcoholic fermentation, which is an anaerobic process (Simanjuntak et al., 2016; Hasanah et al., 2012). The average value of Alcohol Level in Wong tea with fermentation time of 6 days ranged from $0.33 \%$ $0.41 \%$. The formation of alcohol is not only influenced by the presence of sugar, but also substrate conditions such as substrate type, $\mathrm{pH}$, temperature, number of starters, and fermentation conditions. A study by Caturyanti et al. stated that the microbial composition used in cider fermentation affects the quality of the cider produced such as Alcohol Level, sugar content, and sensory assessment (Karak \& Bhagat, 2010; Wong et al., 2018).

Microbes need sugar as a carbon source. Sugar in the media will be used by microbes as nutrients, which will then be converted into alcohol, CO2, and carbonic acid (Silaban, 2005; Purnami et al., 2018). According to Wistiana \& Zubaidah (2015), study it can be explained that the longer the fermentation, the lower the total sugar. This is because sugar is used as a substrate by kombucha culture so that at the end of the fermentation process, alcohol, organic acids, and other metabolites are produced. The decrease in sugar during fermentation is not only caused by the activity of yeast in the metabolism of sugar into alcohol, but also by the activity of Acetobacter which metabolizes glucose into gluconic acid (Desmazeaud, 1996; Dufresne \& Farnworth, 2000; Febrianti et al., 2016; Vitas et al., 2018).

Antarini, A. A. N., Agustini, N. P., \& Mataram, I. K. A. (2022). The effect of using various tea types on the characteristics of wong tea balinese tradisional beverage. International Research Journal of Engineering, IT \& Scientific Research, 8(2), 36-48.

https://doi.org/10.21744/irjeis.v8n2.2060 
Total Acid value is inversely proportional to the $\mathrm{pH}$ value in fermentation. The higher the Total Acid value, the lower the fermentation $\mathrm{pH}$, and vice versa. Based on the results of this study, the Average Values of Total Acid from the treatment of various types of tea can be seen in Figure 15. Total Acid in Wong tea determines the taste of the tea. Different types of tea also affect the Total Acid levels in Wong tea. The higher the Total Acid, the lower the pH. This is because the fermentation process produces organic acids resulting in sour taste. The duration of fermentation has an effect on increasing the Total Acid content of Wong tea. This is because during fermentation, organic acids are produced. The formation of organic acids such as lactic acid in fermentation products is caused by the breakdown of glucose into lactic acid. Lactic acid produced by LAB is excreted out of cells and accumulates in the fermentation liquid so that it increases total acid levels (Dutta \& Paul, 2019). This is in line with a previous study which stated that the total acid content increased with the length of fermentation time in seaweed kombucha. Microbes form energy from carbohydrates, proteins, fats, minerals, and other nutrients in food (substrate). The types of microbes are also similar. What microbes need to have is that they must be able to grow on the substrate and easily adapt to their environment. Microbes must also be able to secrete important enzymes that can carry out the desired chemical changes (Hariyani et al., 2022; Suárez \& Limonta, 2020).

Based on this study, it is known that the total microbes in Wong tea ranged from $8.3 \times 102$ to $3.3 \times 104 \mathrm{cfu} / \mathrm{g}$ which was fermented for 6 days. The presence of substances in each type of tea leaf used in making Wong tea is thought to be due to the presence of soluble solids in Wong tea such as sugar, amino acids, and caffeine. The substances in tea are used as a source of nutrition and energy so that microbial growth increases. Antarini et al. (2017), study found that in Wong tea, the longer the fermentation will increase the total number of microbes. Then, there will be a decrease in fermentation for 9 days and 12 days. The longer the fermentation, the microbial growth will be inhibited and decrease. From the results obtained, it shows that the microbial decrease in each Wong tea is different. This is influenced by the content of phenolic compounds formed during fermentation which are antimicrobial, and causing microbial growth to be inhibited and to decrease (Wistiana \& Zubaidah, 2015).

Lactic acid bacteria are defined as a group of bacteria that form lactic acid, either as the sole product or as the main product of carbohydrate metabolism. Some of the characteristics possessed by lactic acid bacteria are Gram positive, do not form spores, are round or rod-shaped, and generally do not have catalase. From the analysis of Wong tea, Wong tea was identified to have LAB, which was indicated by Gram positive and negative catalase test. Figure 19 shows that there is a significant difference in the total LAB of Wong tea with the use of different types of tea (Bawole et al., 2018; Khezri et al., 2016; Korhenen, 2010). The total LAB produced in Wong tea ranged from $5.8 \mathrm{x}$ $10^{3}$ to $5.1 \times 10^{4} \mathrm{cfu} / \mathrm{g}$. This was influenced by the environment of Wong tea during fermentation. The process produced alcohol so that it could inhibit microbial growth. The results of this study showed that LAB isolates of Wong tea have Gram positive identification, were in the form of bacilli, and these bacteria had negative catalase properties. The increase in LAB is due to the use of sugar, and the decrease is also due to the fact that during the kombucha fermentation process it produces organic acids, alcohol, and other substances that inhibit LAB growth (Wistiana \& Zubaidah, 2015). The substances in Wong tea are used as a source of nutrition and energy so that LAB growth increases. The longer the fermentation, the growth of LAB will be inhibited and decrease. Antarini et al. (2017), study shows that the longer fermentation of Wong tea will increase the total amount of LAB. Then, there will be a decrease in fermentation for 9 days and 12 days. The longer the fermentation, the microbial growth will be inhibited and decrease (Reddy et al., 2015).

Panelists' assessment of the different flavors of Wong tea has an Average Value of 3.45 - 4.68 (neutral - very like), and the quality of taste has an Average Value of 1.98 - 2.27 (slightly sour - sour). Research Habibah et al. (2018), shows that the increase in sour taste is caused by microbial activity in the fermentation process and the increase in the amount of organic acids resulting in sour-tasting drinks. A study shows that the sour taste of the product is caused by the long fermentation time, which causes the $\mathrm{pH}$ to be lower so that the resulting taste will be more acidic (Simanjuntak et al., 2016). This is because yeast and bacteria metabolize sucrose and produce a number of organic acids such as acetic acid, glucuronic acid and gluconic acid (Sujaya et al., 2008; Nur et al., 2015; Nuryadi et al., 2013; Suardana et al., 2007).

Panelists' assessment of the different aromas of Wong tea has an Average Value of 2.97 -3.40 (neutral-like), the quality of the aroma has an Average Value of 1.48 - 2.31 (not sour - slightly sour). As study shows that the aroma contained in tea is caused by the presence of organic acids and the aroma caused by the tea itself (Purnami et al., 2018). The aroma of tea is also caused by volatile compounds such as alcohol, acetic acid, and organic acids that are formed, giving rise to a distinctive sour aroma. A previous study shows that the longer the fermentation, the more acidic the aroma produced in the tea (Habibah et al., 2018). This is due to the lactic acid and acetaldehyde produced 
cause a decrease in the $\mathrm{pH}$ of the fermentation medium or an increase in acidity and cause a distinctive sour aroma in the tea.

Panelists' assessment of the different colors of Wong tea has an Average Value of 3.46 - 4.27 (neutral - like), while color quality has an Average Value of 1.36 - 2.94 (pale yellow - brownish yellow). A study shows that tea contains biochemical bonds, i.e., polyphenols (Taufik et al., 2014). Polyphenol compounds will turn into compounds that produce the desired color, taste, and aroma. The main product of polyphenol oxidation will give a distinctive color to tea brewing. Polyphenols are oxidized to theaflavins and thearubigins. Theaflavin affects the clarity and gives a bright yellow color to the brewed tea, while thearubigin gives the dark brown color to the brewed tea (Srihari \& Satyanarayana, 2012; Yoon et al., 2004).

\section{Conclusion and Recommendations}

Based on the results of data analysis and discussion, it can be concluded that the results of the study are as follows: (1) Organoleptic characteristics of Wong tea based on different types of tea on organoleptic panelists' assessment of taste, aroma, color, and overall acceptance as well as taste quality, aroma quality, and color quality showed significantly different results; (2) Chemical characteristics, including degree of acidity ( $\mathrm{pH}$ ), total soluble solids, Total Acid, and Alcohol Level in Wong tea, showed no significant difference, while antioxidant activity and phenol levels showed significant differences between treatment groups; (3) Microbial characteristics, including total microbial and total LAB of Wong tea, showed no significant difference. The recommendations from this study are as follows: (1) To get the preferred Wong tea, the type of tea in Treatment 2 can be used and the Wong tea storage area can be conditioned in a stable and cool temperature and humidity; (2) For future research, further identification and selection of LAB for probiotic beverage candidates can be carried out.

\section{Conflict of interest statement}

The authors declared that they have no competing interest.

\section{Statement of authorship}

The authors have a responsibility for the conception and design of the study. The authors have approved the final article.

\section{Acknowledgments}

Further thanks to the director and head of the department of nutrition Denpasar for the support that has been given. Also to the Head of the Laboratory of Basic Sciences, Faculty of Agriculture, Warmadewa University, Denpasar and the Laboratory for Testing, thank you for doing the analysis.

Antarini, A. A. N., Agustini, N. P., \& Mataram, I. K. A. (2022). The effect of using various tea types on the characteristics of wong tea balinese tradisional beverage. International Research Journal of Engineering, IT \& Scientific Research, 8(2), 36-48. 


\section{References}

Agestiawan, I. G. A. M., Swastini, D. A., \& Ramona, Y. (2014). Uji Ketahanan Bakteri Asam Laktat Yang Diisolasi Dari Kimchi Terhadap pH Rendah. Jurnal Farmasi Udayana, 3(2), 279858.

Antarini, A. A. N., Agustini, N. P., Sudita Puryana, I., Wiardani, N. K., \& Mallongi, A. (2018). Identification of Microbes, Chemical, and Organoleptic Characteristics towards Teh Wong during Fermentation. Indian Journal of Public Health Research \& Development, 9(5).

Antarini, L., Suryana, I. N. M., \& Sudemen, I. W. (2017). Tingkat Kepuasan Layanan Mahasiswa Universitas Warmadewa Tahun 2017. SINTESA (Jurnal Ilmu Sosial dan Ilmu Politik), 8(1), 12-16.

Apriyantono, A., Fardiaz, D., Puspitasari, N. L., Sedarnawati, B. S., \& Budiyanto, S. (1989). Analisis pangan.

Bawole, K. V., Umboh, S. D., \& Tallei, T. E. (2018). Uji Ketahanan Bakteri Asam Laktat Hasil Fermentasi Kubis Merah (Brassica oleracea L.) Pada pH 3. Jurnal MIPA, 7(2), 20-23.

Coton, M., Pawtowski, A., Taminiau, B., Burgaud, G., Deniel, F., Coulloumme-Labarthe, L., ... \& Coton, E. (2017). Unraveling microbial ecology of industrial-scale Kombucha fermentations by metabarcoding and culture-based methods. FEMS Microbiology Ecology, 93(5).

Desmazeaud, M. (1996). Lactic acid bacteria in food: use and safety. Cahiers d'Etudes et de Recherches Francophones Agricultures (France).

Dufresne, C., \& Farnworth, E. (2000). Tea, Kombucha, and health: a review. Food research international, 33(6), 409-421.

Dutta, H., \& Paul, S. K. (2019). Kombucha drink: production, quality, and safety aspects. In Production and management of beverages (pp. 259-288). Woodhead Publishing.

Febrianti, A. N., Suardana, I. W., \& Suarsana, I. N. (2016). Ketahanan Bakteri Asam Laktat (BAL) Isolat 9A Hasil Isolas dari Kolon Sapi Bali terhadap $\mathrm{pH}$ Rendah dan Natrium Deoksikolat (NaDC). Indonesia Medicus Veterinus, 5(5), 415-421.

Fessard, A., Kapoor, A., Patche, J., Assemat, S., Hoarau, M., Bourdon, E., ... \& Remize, F. (2017). Lactic fermentation as an efficient tool to enhance the antioxidant activity of tropical fruit juices and teas. Microorganisms, 5(2), 23.

Gaspersz, V. (1995). Teknik analisis dalam penelitian percobaan. Tarsito. Bandung, 718.

Guo, X., Wang, C., Sun, F., Zhu, W., \& Wu, W. (2014). A comparison of microbial characteristics between the thermophilic and mesophilic anaerobic digesters exposed to elevated food waste loadings. Bioresource technology, 152, 420-428. https://doi.org/10.1016/j.biortech.2013.11.012

Habibah, I., Mahadi, I. \& Sayuti, I. (2018). The Effect of Variation of Tea (Camella sinensis L Kuntze) Processing and Sugar Concentration to Kombucha Fermentation as Senior High School Student Biology Worksheet. Study Program of Biology Education.

Habibah, I., Mahadi, I. \& Sayuti, I. (2018). The Effect of Variation of Tea (Camella sinensis L Kuntze) Processing and Sugar Concentration to Kombucha Fermentation as Senior High School Student Biology Worksheet. Study Program of Biology Education.

Hariyani, S., Wattini, W., Zuraida, I., Kurniawan, P., Marini, L., \& Rianty, E. (2022). The effect of adding probiotic bacteria on bauxite waste mud: Experimental research method. International Journal of Engineering \& Computer Science, 5(1), 1-13. https://doi.org/10.21744/ijecs.v5n1.1818

Hasanah, A. N., Rizkiana, F., \& Rahayu, D. (2012). Banana peels and stem (Musax paradisiaca Linn.) as biosorbent of copper in textile industry wastewater. Research Journal of Pharmaceutical, Biological and Chemical Sciences, 3(3), 1171-1178.

Hastuti, R. (2014). Tax awareness and tax education: A perception of potential taxpayers. Tax Awareness And Tax Education: A Perception Of Potential Taxpayers, 5.

Hopkins, D. W., Wiltshire, P. E. J., \& Turner, B. D. (2000). Microbial characteristics of soils from graves: an investigation at the interface of soil microbiology and forensic science. Applied Soil Ecology, 14(3), 283-288. https://doi.org/10.1016/S0929-1393(00)00063-9

Huang, L., Weng, X., Chen, Z., Megharaj, M., \& Naidu, R. (2014). Green synthesis of iron nanoparticles by various tea extracts: comparative study of the reactivity. Spectrochimica Acta Part A: Molecular and Biomolecular Spectroscopy, 130, 295-301. https://doi.org/10.1016/j.saa.2014.04.037

Ilango, S., \& Antony, U. (2021). Probiotic microorganisms from non-dairy traditional fermented foods. Trends in Food Science \& Technology, 118, 617-638. https://doi.org/10.1016/j.tifs.2021.05.034

Karak, T., \& Bhagat, R. M. (2010). Trace elements in tea leaves, made tea and tea infusion: A review. Food research international, 43(9), 2234-2252. https://doi.org/10.1016/j.foodres.2010.08.010 
Kaur, P., Ghoshal, G., \& Banerjee, U. C. (2019). Traditional bio-preservation in beverages: fermented beverages. In Preservatives and preservation approaches in beverages (pp. 69-113). Academic Press. https://doi.org/10.1016/B978-0-12-816685-7.00003-3

Khezri, S., Dehghan, P., Mahmoudi, R., \& Jafarlou, M. (2016). Fig juice fermented with lactic acid bacteria as a nutraceutical product. Pharmaceutical Sciences, 22(4), 260-266.

Korhenen, J. (2010). Forestry and Natural Sciences.

Kraujalytė, V., Pelvan, E., \& Alasalvar, C. (2016). Volatile compounds and sensory characteristics of various instant teas produced from black tea. Food Chemistry, 194, 864-872. https://doi.org/10.1016/j.foodchem.2015.08.051

Kung Jr, L., Shaver, R. D., Grant, R. J., \& Schmidt, R. J. (2018). Silage review: Interpretation of chemical, microbial, and organoleptic components of silages. Journal of dairy Science, 101(5), 4020-4033. https://doi.org/10.3168/jds.2017-13909

Naland, H. (2004). Kombucha teh ajaib pencegah dan penyembuh aneka penyakit. Indonesian: AgroMedia Pustaka, Jakarta.

Nur, F., Hafsan, H., \& Wahdiniar, A. (2015). Isolasi bakteri asam laktat berpotensi probiotik pada dangke, makanan tradisional dari susu kerbau di Curio Kabupaten Enrekang. Biogenesis: Jurnal Ilmiah Biologi, 3(1), 60-65.

Nuryadi, M. M., Istiqomah, T., Faizah, R., Uabidillah, S., \& Mahmudi, Z. (2013). Isolasi dan identifikasi bakteri asam laktat asal youghurt. Journal University of Jember, 1(5), 1-11.

Purnami, K. I., Jambe, A. A., \& Wisaniyasa, N. W. (2018). Pengaruh jenis teh terhadap karakteristik teh kombucha. Jurnal Ilmu dan Teknologi Pangan, 7(2).

Reddy, L. V., Min, J. H., \& Wee, Y. J. (2015). Production of probiotic mango juice by fermentation of lactic acid bacteria. Microbiology and Biotechnology Letters, 43(2), 120-125.

Ruslin, Sahumena, M. H., Andriani, R., Manangkara, M.,Mistriyani \& Yamin. (2021). In Vitro Antioksidan Activity Test and Determination of phenolic and Flavonoid Content of Moringa Oleifera pulp and seeds. Journal Food Research 5(4) : $59-65$.

Silaban, B. (2005). Efektifitas Model Pengajaran Berdasarkan-Masalah (Problem-Based Instruction) Dalam Mengajarkan Fisika Di SMU. PPKn, 6(7.22), 5-57.

Simanjuntak, D. H., Herpandi, H., \& Lestari, S. D. (2016). Karakteristik Kimia dan Aktivitas Antioksidan Kombucha dari Tumbuhan Apu-apu (Pistia stratiotes) Selama Fermentasi. Jurnal FishtecH, 5(2), 123-133.

Sreeramulu, G., Zhu, Y., \& Knol, W. (2000). Kombucha fermentation and its antimicrobial activity. Journal of Agricultural and Food Chemistry, 48(6), 2589-2594.

Srihari, T., \& Satyanarayana, U. (2012). Changes in free radical scavenging activity of kombucha during fermentation. Journal of Pharmaceutical Sciences and Research, 4(11), 1978.

Suardana, I. W., Suarsana, I. N., Sujaya, I. N., \& Wiryawan, K. G. (2007). Isolasi dan identifikasi bakteri asam laktat dari cairan rumen sapi bali sebagai kandidat biopreservatif. Jurnal veteriner, 8(4), 155-159.

Suárez, M. C. G., \& Limonta, S. M. C. (2020). Psychological overcoming: effective tool for karate-do trainers. International Journal of Engineering \& Computer Science,3(1), 31-35. https://doi.org/10.31295/ijecs.v3n1.1000

Sudarmadji, S. B., Haryono \& Suhardi. (1997). Analisa Bahan Makanan dan Pertanian. Liberty. Yogyakarta.

Sujaya, N., Ramona, Y., Widarini, N. P., Suariani, N. P., Dwipayanti, N. M. U., Nocianitri, K. A., \& Nursini, N. W. (2008). Isolasi dan karakterisasi bakteri asam laktat dari susu kuda Sumbawa. Jurnal Veteriner, 9(2), 52-59.

Sutarmi, M. (2005). Pengembangan Produk Kombucha Probiotik Berbahan Baku Teh Hijau Dan Teh Oolong (Doctoral dissertation, Bogor Agricultural University).

Taufik, Y., Garnida, Y., \& Juliandini, N. T. (2014). Mempelajari Pengaruh Konsentrasi Sukrosa Dan Konsentrasi Ekstrak Teh Hitam Terhadap Minuman Teh (Camellia Sinensis) DALAM KEMASAN.

Tyagi, S. K., Manikantan, M. R., Oberoi, H. S., \& Kaur, G. (2007). Effect of mustard flour incorporation on nutritional, textural and organoleptic characteristics of biscuits. Journal of Food Engineering, 80(4), 1043-1050. https://doi.org/10.1016/j.jfoodeng.2006.08.016

Vitas, J. S., Cvetanović, A. D., Mašković, P. Z., Švarc-Gajić, J. V., \& Malbaša, R. V. (2018). Chemical composition and biological activity of novel types of kombucha beverages with yarrow. Journal of Functional Foods, 44, 95102.

Wistiana, D., \& Zubaidah, D. (2015). E. Chemical and Microbiological Characteristics of Kombucha from Various High Leaf Phenols During Fermentation. Jurnal Pangan dan Agroindustri, 3(4), 1446-145.

Antarini, A. A. N., Agustini, N. P., \& Mataram, I. K. A. (2022). The effect of using various tea types on the characteristics of wong tea balinese tradisional beverage. International Research Journal of Engineering, IT \& Scientific Research, 8(2), 36-48.

https://doi.org/10.21744/irjeis.v8n2.2060 
Wong, S., Lim, Y., Ngadi, N., Mat, R., Hassan, O., Inuwa, I. M., ... \& Low, J. H. (2018). Removal of acetaminophen by activated carbon synthesized from spent tea leaves: equilibrium, kinetics and thermodynamics studies. Powder Technology, 338, 878-886. https://doi.org/10.1016/j.powtec.2018.07.075

Yoon, K. Y., Woodams, E. E., \& Hang, Y. D. (2004). Probiotication of tomato juice by lactic acid bacteria. Journal of microbiology, 42(4), 315-318. 